\title{
Introducing GloRiSe - a global database on river sediment composition
}

\author{
Gerrit Müller, Jack J. Middelburg, and Appy Sluijs \\ Department of Earth Sciences, Utrecht University, Utrecht, the Netherlands \\ Correspondence: Gerrit Müller (g.muller@uu.nl)
}

Received: 18 January 2021 - Discussion started: 25 January 2021

Revised: 25 May 2021 - Accepted: 27 May 2021 - Published: 29 July 2021

\begin{abstract}
Rivers transport dissolved and solid loads from terrestrial realms to the oceans and between inland reservoirs, representing major mass fluxes on Earth's surface. The composition of river water and sediment provides clues to a plethora of Earth and environmental processes, including weathering, erosion, nutrient and carbon cycling, environmental pollution, reservoir exchange, and tectonic cycles. While there are documented, publicly available databases for riverine dissolved and suspended nutrients, there is no openly accessible, georeferenced database for riverine suspended sediment composition. Here, we present a globally representative set of 2828 suspended and bed sediment compositional measurements from 1683 locations around the globe. This database, named Global River Sediments (GloRiSe) version 1.1, includes major, minor and trace elements, along with mineralogical data, and provides time series for some sites. Each observation is complemented by metadata describing geographic location, sampling date and time, sample treatment, and measurement details, which allows for grouping and selection of observations, as well as for interoperability with external data sources, and improves interpretability. Information on references, unit conversion and references makes the database comprehensible. Notably, the close to globe-spanning extent of this compilation allows the derivation of data-driven, spatially resolved global-scale conclusions about the role of rivers and processes related to them within the Earth system.

GloRiSe version 1.1 can be downloaded from Zenodo (https://doi.org/10.5281/zenodo.4485795, Müller et al., 2021) and GitHub (https://github.com/GerritMuller/GloRiSe, last access: 26 May 2021), where updates with adapted version numbers will become available, along with a technical documentation and an example calculation in the form of MATLAB scripts, which calculate the sediment-flux-weighted major element composition of the annual riverine suspended sediment export to the ocean and related uncertainties.
\end{abstract}

\section{Introduction}

Rivers are major drivers of material transport, processing and deposition on Earth's surface (Martin and Meybeck, 1979; Milliman and Farnsworth, 2011; Viers et al., 2009). This makes them important for ecosystem functioning within the respective catchment and in the coastal oceans or lakes they feed (Allan and Castillo, 2007; Meybeck, 1982). Flora and fauna (including humans) often live along rivers and at their mouths, because they provide freshwater, nourishment, energy and effective possibilities of transportation (Allan and Castillo, 2007). Increasing human populations have led to environmental pollution and disturbance of natural processes
(Martin and Meybeck, 1979; Nienhuis et al., 2020; Vörösmarty et al., 2010). For instance, increased nutrient input related to land-use change and agricultural activities (Beusen et al., 2016; McDowell et al., 2020b; Weigelhofer et al., 2018), acidification and heavy metal contamination (Kumar et al., 2019), harm biodiversity and people around the globe, and damming increasingly affects riverine fluxes, processes and ecosystems (Mulligan et al., 2020; Vörösmarty et al., 2010). As transporters of solutes and solids, rivers play a major role in terrestrial weathering and erosion and thereby in the global carbon cycle, mediating atmospheric greenhouse gas concentrations and thus climatic stability of the 
Earth system on geologic timescales (Berner, 2003; Caves Rugenstein et al., 2019; Isson et al., 2020). Riverine suspended sediment fluxes of organic carbon (Berner, 1982; Hilton and West, 2020), phosphorous (Berner, 1999; Froelich et al., 1982) and biogenic silica (Conley, 2002) are considered dominant terms in their global budgets, and a similar importance was proposed for the riverine particulate fluxes of calcium (Gislason et al., 2006), strontium (Jones et al., 2012) and inorganic carbon (Middelburg et al., 2020). Moreover, significant amounts of divalent cations weakly bound to the negatively charged (clay) mineral surfaces are transported downstream with the suspended particles, and this complicates estimates of weathering rates (Cerling et al., 1989; Tipper et al., 2021). Superimposed on the lithological composition of the catchment, the interplay of terrestrial weathering and erosion defines the composition of water and sediment input to the rivers and the magnitude of the corresponding fluxes. Therefore, dependencies of weathering and erosion can be studied through the river composition in comparison to environmental variables (Gaillardet et al., 1999; Hartmann et al., 2014b; Romero-Mujalli et al., 2019). Extensive datasets describing riverine hydrochemistry (GLORICH, Hartmann et al., 2014a; nitrogen and phosphorous, McDowell et al., 2020a) and environmental variables (e.g. HydroBASINS; Linke et al., 2019) have recently been established. Databases on water and sediment discharge have been developed (e.g. GEMS-GLORI; Meybeck and Ragu, 1997; Milliman and Farnsworth, 2011; Land2Sea PeuckerEhrenbrink, 2009). In contrast, established major and trace element budgets of river suspended sediment (Martin and Meybeck, 1979; Savenko, 2007; Viers et al., 2009) are not easily (if at all) accessible, comprehensible or fully traceable, leaving much of their potential unexplored. To our knowledge, no current database summarizes the mineralogical and petrographic composition of global river sediments. To fill this gap we compiled published (108 articles) - mostly peerreviewed (104) - major, minor and trace element, mineralogical and petrographic data of 2828 suspended and bed sediment samples taken at 1683 different worldwide locations between 1874 and 2016. Complementary metadata provide a spatio-temporal context and facilitate traceability of each data point, grouping/selection operations within and interoperability of this database, named Global River Sediment (GloRiSe). Practically, these data may be used, for example, for (spatial) statistical modelling and model testing, to complement local or regional datasets, to explore and compare time series at different locations, to screen potential for field studies, to assess anthropogenic pollution or to characterize the material transported to the global ocean and freshwater reservoirs. Notably, the globe-spanning extent of the database allows the derivation of data-driven global-scale conclusions about the role of rivers and processes related to them within the Earth system. In this article, we explain the derivation, harmonization and structure of the database, comment on its extent and limitation, and complement this by an example application, the calculation of the major element composition of the annual riverine suspended sediment export to the ocean.

\section{Data collection}

Data were collected during a literature survey between March and September 2020 of studies with local to global extent. The survey aimed at suspended sediment samples, being best representative of two potential fields of application: (a) the integrated chemical weathering history of the catchment (von Eynatten, 2004; Guo et al., 2018; He et al., 2020; Nesbitt and Young, 1982) and (b) the characterization of terrestrial riverine material transport and export (Ludwig et al., 1996; Milliman and Farnsworth, 2011). Riverbed sediments were primarily considered where no information on suspended sediment samples was found (especially in Africa) and marked specifically. If available, grain size information was included as well (sieve and/or filter pore size, average grain size, sand/silt/clay percentage). The fine fraction, i.e. clay- and silt-sized particles, of present and past riverine deposits is often considered a compositional tracer for riverine suspended load (Fedo et al., 1995; Garzanti et al., 2015; Guo et al., 2018; Nesbitt and Young, 1982). However, there is an effect of hydrodynamic sorting during deposition, affecting sediment composition (Bouchez et al., 2011; von Eynatten et al., 2012; Galy et al., 2007; Garzanti et al., 2010, 2011; Horowitz and Elrick, 1987; Lupker et al., 2011). Dissolution, precipitation, particle break-down and resuspension along the river further alter their chemical composition (Cole et al., 2007; Ensign and Doyle, 2006; Lupker et al., 2012; Nakato, 1990; Négrel and Grosbois, 1999; Papanicolaou et al., 2008). These findings need to be considered in the selection of GloRiSe data for a specific application. Because included samples should at least resemble the complete inorganic composition of suspended matter, no studies were included, in which samples were decarbonated before analysis (e.g. Bayon et al., 2015; Liu et al., 2007, 2012). Other sample treatments, such as oxidation, fusion or digestion, were noted.

Previous compilations served as a starting point of our survey (Viers et al., 2009) or were incorporated (Martin and Meybeck, 1979, and Meybeck and Ragu, 1997), depending on their content. Studies were selected that report either inorganic major and minor element composition $(\mathrm{Si}, \mathrm{Al}, \mathrm{Ca}$, $\mathrm{Mg}, \mathrm{K}, \mathrm{Na}, \mathrm{Fe}, \mathrm{Mn}$, Ti, P, S, C, loss on ignition - together 2412 observations) and/or a (semi-)quantitative mineralogical phase analysis (876 observations). Organic C, P, N and trace elements were only added when they were reported along with the major element or mineralogical data, implying that there is ample room to further expand GloRiSe using published data. Nevertheless, 1906 observations of selected trace elements and 700 observations of organic $C$ were collected. Organic $\mathrm{P}$ and $\mathrm{N}$ are highly under-represented. 
When instantaneous water discharge and/or suspended sediment concentration and/or solution properties $(T, \mathrm{pH}$, alkalinity, $\mathrm{Si}(\mathrm{OH})_{4}, \mathrm{DIC}, \mathrm{DOC}, \mathrm{HCO}_{3}^{-}, \mathrm{SO}_{4}^{2-}, \mathrm{Cl}^{-}, \mathrm{Ca}^{2+}$, $\mathrm{Mg}^{2+} \mathrm{Na}^{+}, \mathrm{K}^{+}$, calcite saturation) were reported in the same study, these were also added for comparison. However, the focus of data collection remains on the composition of solid phases, and detailed information on water chemistry is available from other sources (Hartmann et al., 2014a; McDowell et al., 2020a; Virro et al., 2021). Doublings with entries of other databases were not checked. Unit conversion is detailed in Appendix A. Studies were furthermore only included if geographic coordinates were given or were retrieved on the basis of given maps and/or site names. For spatial averages (21 samples denoted "sa" as the "observation type"), coordinates in the centre of the location distribution were chosen (range $<1$ to $\sim 5^{\circ}$ latitude-longitude). Country and region of the measurement were also noted following details given in the specific study. The closest information on sampling date is given for each observation, which can range in resolution from some years to minutes but is the day or month in most cases. However, many authors did not mention sampling date. In these cases, a user may choose to apply the publication date from the linked references (if appropriate), post-dating sampling. Seasonal (26) and annual (143) averages were also included if the original measurements were not accessible, which is especially the case for older publications (before $\sim 2000$ ).

\section{Database structure}

The structure of the database employs that of the complementary GLORICH database (Hartmann et al., 2014a) listing variables in columns and identifiers, metadata and observations in rows. It consists of six separate tables, in which samples are linked via a unique Sample_ID, which in turn can be related to a Location_ID that is similar for all observations from exactly the same site. Locations that are situated within the same main basin were assigned the same Basin_ID that allows grouping observations in terms of catchment without further processing using geographic information systems (GISs). A main basin delineates everything that drains into the same river that is a tributary only to the ocean (or a lake for endorheic drainage) and was assessed by visually tracing the streams to their mouth (using () Google Earth 2020). The Rep_ID was introduced, allowing distinguishing samples that are representative of the export to the ocean in terms of sampling position in the lower course of the main stem river but before significant marine influence, from upstream and tributary observations or endorheic drainages. Marine influence was assessed using tidal maps (Matthews, 2014), coastal landforms (C Google Earth 2020) and, where available, information on salinity gradients or assignment of freshwater endmembers. The Rep_ID also allows distinguishing observations during storm events or flood events, although the assignment of this relied on information provided in the source article. All information necessary to identify and retrace a sample, such as the IDs assigned by us, its original ID used in the original study, sampling date and references, is stored within a separate table. Information on each variable is given in each file, and a technical documentation and explanatory script can be downloaded together with the database.

\section{Extent and limitations}

The database covers a representative set of downstream observations from all over the globe except for Antarctica, but it leaves larger gaps in upstream and endorheic areas (Fig. 1). Further gaps are identified in parts of northern and central Canada, western USA, Central America, western South America, Brazil, northwestern Africa and Oceania (Fig. 1). Although a few observations from south-west Greenland and central east Greenland are included, they are unlikely representative for Greenland sediment discharge as a whole. Upstream measurements are also not available for many parts of the world.

In contrast to the globally representative spatial coverage, temporal coverage is very low; i.e. there are few time series included. This is mostly because there are very few time series and concentration-discharge relationships available in the literature.

The number of available variables differs between the samples in respect to the original purpose of data acquisition. Consequently, depending on the user's aim, the number of suitable observations may decrease drastically; i.e. the more variables needed, the fewer data points are available. This aggravates the problem if the database is to be combined with other (point) data sources, because the range of intersecting locations might be small or require a decrease in spatial resolution by, for example, rounding coordinates or integrating over geographic shape layers. The database does obviously not (yet) cover the whole overwhelming amount of data on river sediment composition in the literature but is intended to be further expanded. We therefore ask users not only to provide feedback but also to contribute to extension of the database by sending us (also unpublished) suitable data with proper metadata to be included.

\section{Possibilities and perspectives}

To demonstrate some important possibilities and perspectives of the database, we provide an example of MATLAB script for the calculation of the average major element composition of the global riverine suspended sediment export, including the combination with external data sources (Milliman and Farnsworth, 2011) and detailed comments. In this example, we exclude riverbed sediment samples coarser than very fine sand (grain sizes $>125 \mu \mathrm{m}$ or unknown) to rep- 


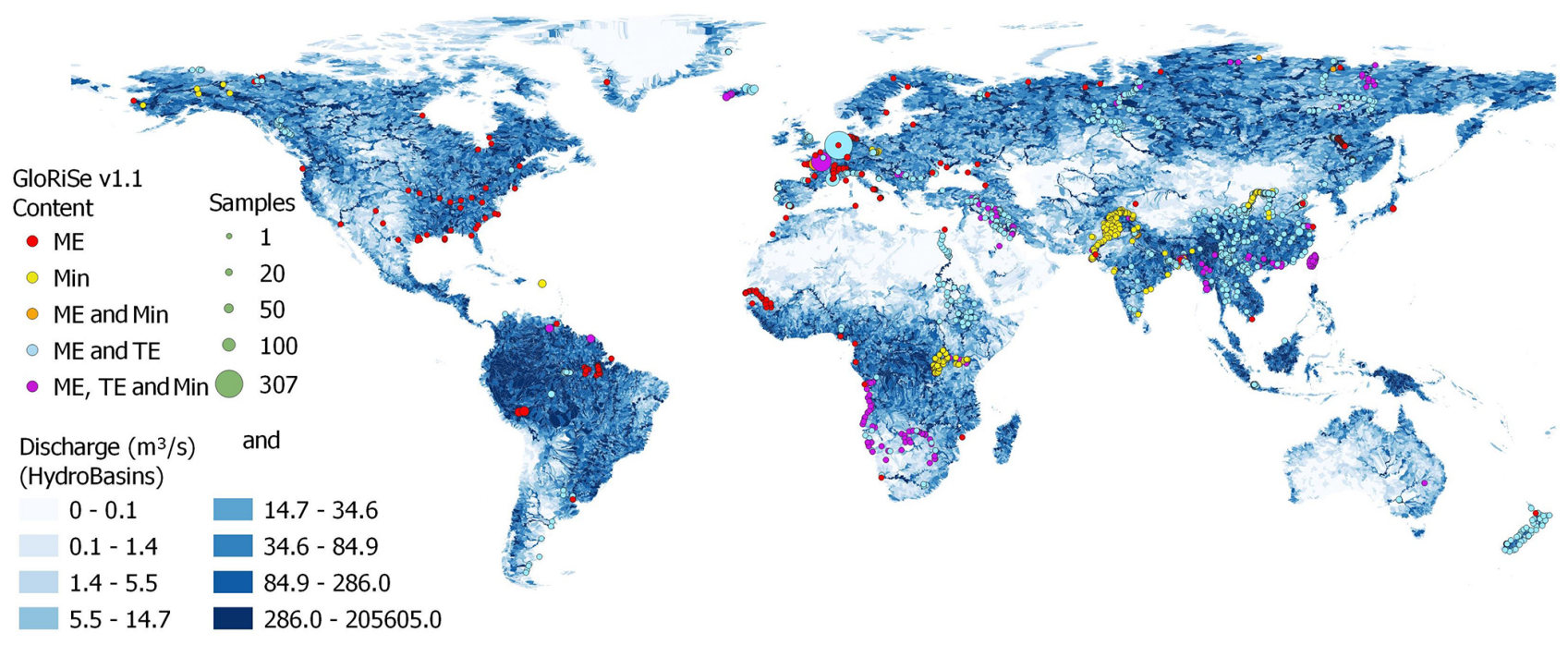

Figure 1. Spatial extent of the database. Dot size indicates the number of samples available per location. Dot colour indicates what kind of data are available at that location (ME: major and minor elements, TE: trace elements, Min: mineralogical or petrological composition). River water discharge, as indicated by blue colouration, was taken from the HydroBASINS database at Pfaffstetter level 7 (Linke et al., 2019).

resent only suspended sediment. Samples were split up according to their observation type into single measurements and spatial averages (I), seasonal averages (II) and annual averages (III). Rep_ID and Basin_ID are used to select only samples from river main stems that represent the basin sediment discharge to the ocean. For each basin in the subsets (I) and (II), mean and median major element concentrations are calculated, representing annual averages for each set. All subsets are then recombined, and an annual mean and median are re-calculated for each basin. These data are then merged with annual average sediment discharge values based on the river names (Milliman and Farnsworth, 2011) to calculate basin-wise fluxes of each major element oxide. We then calculated the global mean and median concentrations of each oxide from the basin-wise mean and median, respectively, and the sediment-flux-weighted (sfw) mean. These estimates are based on samples that can be considered spatially representative and probe $\sim 35 \%$ of the total global sediment flux considering 19.1 Pg/a (Beusen et al., 2005; Milliman and Farnsworth, 2011). Uncertainties are based on estimates of the temporal variability of sediment composition and fluxes (Appendix B). Estimates of the concentrations of major cations sorbed to negatively charged surfaces were derived using a published linear relationship between molar $\mathrm{Al} / \mathrm{Si}$ ratios and cation exchange capacity (CEC), along with estimates of the average major element composition of this sorbed pool (Tipper et al., 2021). Table 1 holds the results normalized to a total of $100 \%$ along with respective uncertainties, contributions of the sorbed pool and previous estimates for global average major element composition. Unnormalized and intermediate results are available through the tutorial script and can directly be downloaded with the script.
The median differs from -2.9 to $+1.2 \mathrm{wt} \%$ from the mean and is preferred for all oxides except for $\mathrm{SiO}_{2}$ and $\mathrm{MnO}$ because of their log-normal distribution. Results for major and minor elements sum to $75 \%-85 \%$; the rest is accounted for by organic matter, degassing during sample preparation (e.g. $\mathrm{CO}_{2}$ and $\mathrm{H}_{2} \mathrm{O}$ degassing upon fusion) and uncertainty. Generally, our global mean estimates of $\mathrm{SiO}_{2}, \mathrm{MgO}$ and $\mathrm{Na}_{2} \mathrm{O}$ appear to be higher than previous estimates from the literature, while $\mathrm{Al}_{2} \mathrm{O}_{3}$ and $\mathrm{Fe}_{2} \mathrm{O}_{3}$ mean values are lower (Table 1). $\mathrm{CaO}, \mathrm{MnO}, \mathrm{K}_{2} \mathrm{O}, \mathrm{TiO}_{2}$ and $\mathrm{P}_{2} \mathrm{O}_{5}$ are within the range of the selected literature estimates. Part of the similarity to the results of Viers et al. (2009) and Martin and Meybeck (1979) originates from common data sources: most of the compilation of Viers et al. (2009) and the data of Martin and Meybeck (1979) were incorporated into GloRiSe. However, Viers et al. (2009) used the mean of main stem and tributary measurements, while Martin and Meybeck (1979) report the median of downstream mainstem locations. The derivation of the values presented in Savenko (2007) is not retraceable, so we cannot evaluate possible common data sources. High sample standard deviations exceeding the actual concentration for some alkali and alkaline Earth elements (Table 1) again stress the heterogeneous and timevariant nature of riverine suspended sediment composition (Clark et al., 2017; Eberl, 2004; Eiriksdottir et al., 2008; van der Perk and Vilches, 2020; Rousseau et al., 2019). Compared to the continental crust (Rudnick and Gao, 2014), $\mathrm{Na}_{2} \mathrm{O}, \mathrm{K}_{2} \mathrm{O}$ and $\mathrm{CaO}$ are generally depleted in riverine suspended sediments, while $\mathrm{Al}_{2} \mathrm{O}_{3}, \mathrm{Fe}_{2} \mathrm{O}_{3}$ and $\mathrm{TiO}_{2}$ are enriched. This can be explained by weathering, transforming pristine mineral phases (e.g. feldspar, mafic minerals and calcite) into dissolved load and secondary phases (Putnis et al., 2014; Ruiz-Agudo et al., 2016). Well-soluble elements (Na, 
Table 1. Global average major element composition of riverine suspended matter discharged to the ocean in weight $\%$ relative to total suspended matter and normalized to $100 \%$ excluding organic matter and oxides often lost during preparation $\left(\mathrm{e} . \mathrm{g}\right.$. $\mathrm{CO}_{2}$ and $\left.\mathrm{H}_{2} \mathrm{O}\right)$. The mean, median and sediment-flux-weighted average of this study are compared to previous estimates from the literature. $T$ denotes the total concentration of ferric + ferrous Fe or organic + inorganic P, respectively. CIX is a chemical alteration index calculated on a molar basis (Garzanti et al., 2014; Eq. 1). The error estimate belongs to the flux-weighted mean and does account for sampling-time-induced uncertainty and sample standard deviation and number of samples $(N)$. Sorbed load was calculated based on published $\mathrm{CEC}, \mathrm{Al} / \mathrm{Si}$ ratios, and mean fraction of $\mathrm{Ca}, \mathrm{Mg}, \mathrm{Na}$ and $\mathrm{K}$ in the sorbed pool (Tipper et al., 2021).

\begin{tabular}{|c|c|c|c|c|c|c|c|c|c|c|c|}
\hline & $\mathrm{SiO}_{2}$ & $\mathrm{Al}_{2} \mathrm{O}_{3}$ & $\mathrm{Fe}_{2} \mathrm{O}_{3} T$ & $\mathrm{MnO}$ & $\mathrm{CaO}$ & $\mathrm{MgO}$ & $\mathrm{K}_{2} \mathrm{O}$ & $\mathrm{Na}_{2} \mathrm{O}$ & $\mathrm{TiO}_{2}$ & $\mathrm{P}_{2} \mathrm{O}_{5} T$ & CIX \\
\hline Mean this study & 65.3 & 16.1 & 7.4 & 0.2 & 3.6 & 2.2 & 2.2 & 1.9 & 0.9 & 0.3 & 73.74 \\
\hline Median this study & 68.2 & 15.9 & 6.7 & 0.1 & 2.3 & 1.9 & 2.3 & 1.6 & 0.8 & 0.2 & 74.42 \\
\hline Flux-weighted mean this study (suggested) & 65.1 & 18.7 & 6.3 & 0.1 & 2.9 & 2.1 & 2.7 & 1.1 & 0.8 & 0.1 & 76.71 \\
\hline Sorbed load in sfw mean & & & & & 0.66 & 0.10 & 0.02 & 0.02 & & & \\
\hline Sample SD this study & 15.0 & 4.6 & 3.4 & 0.1 & 3.7 & 1.2 & 0.9 & 1.2 & 0.5 & 0.3 & \\
\hline Max uncertainty in time series & 29.3 & 11.0 & 4.3 & 0.3 & 10.5 & 1.2 & 1.4 & 0.6 & 0.4 & 0.6 & \\
\hline Mean uncertainty in time series & 7.0 & 5.5 & 1.2 & 0.1 & 1.6 & 0.4 & 0.5 & 0.2 & 0.2 & 0.1 & \\
\hline$N$ & 156 & 174 & 174 & 173 & 174 & 173 & 171 & 169 & 144 & 145 & \\
\hline Uncertainty in this study & 2.7 & 2.3 & 1.1 & 0.2 & 1.3 & 0.7 & 0.7 & 0.4 & 0.4 & 0.2 & 0.1 \\
\hline Viers et al. (2009) & 58.0 & 19.9 & 10.0 & 0.3 & 4.4 & 2.5 & 2.5 & 1.2 & 0.9 & 0.4 & 78.98 \\
\hline Martin and Meybeck (1979) & 61.1 & 20.2 & 7.8 & 0.2 & 3.4 & 2.2 & 2.7 & 1.1 & 1.1 & 0.2 & 78.03 \\
\hline Savenko (2007) & 58.6 & 19.8 & 8.7 & 0.2 & 4.4 & 2.9 & 3.1 & 1.3 & 0.8 & 0.2 & 74.93 \\
\hline Continental crust (Rudnick and Gao, 2014) & 66.6 & 15.1 & 4.1 & 0.1 & 4.2 & 2.3 & 3.2 & 3.6 & 0.5 & 0.2 & 62.32 \\
\hline
\end{tabular}

$\mathrm{K}, \mathrm{Mg}$ and $\mathrm{Ca}$ ) will preferably be transported as a dissolved load, leaving rather insoluble elements $(\mathrm{Al}, \mathrm{Fe}, \mathrm{Ti})$ enriched in the secondary phase (Gaillardet et al., 1999; Garzanti et al., 2014; Middelburg et al., 1988; Nesbitt and Young, 1982; Stroncik and Schmincke, 2001). Consequently, the unweathered source rock is relatively rich in mobile elements and also more reactive (Brantley et al., 2008; Lasaga, 1984). To quantify the relative contribution of weathered and unweathered material to fine-grained sediment samples, reflecting weathering intensity within the sediments source area, different chemical weathering indices have been developed (Fedo et al., 1995; Gaillardet et al., 1999; Garzanti et al., 2013, 2014; Harnois, 1988; Nesbitt and Young, 1982; Parker, 1970). Most of them are based on the relative concentrations of mobile to quasi-insoluble elements (Fedo et al., 1995; Garzanti et al., 2014; Harnois, 1988; Nesbitt and Young, 1982; Parker, 1970), each involving different elements and related pitfalls. For the current application, where we lack sufficient information on dissolved concentrations and do not expect a strong diagenetic imprint, but need to account for carbonate- and phosphate-related $\mathrm{CaO}$, we use the chemical index of alteration CIX (Garzanti et al., 2014):

$\mathrm{CIX}=100 \times \mathrm{Al}_{2} \mathrm{O}_{3} /\left(\mathrm{Al}_{2} \mathrm{O}_{3}+\mathrm{Na}_{2} \mathrm{O}+\mathrm{K}_{2} \mathrm{O}\right)$.

We neglect the contributions of sorbed $\mathrm{Na}_{2} \mathrm{O}$ and $\mathrm{K}_{2} \mathrm{O}$, because their magnitude is small compared to solid concentrations (Table 1). High CIX values imply a large contribution of weathered material, while a low CIX, similar to that of parent rocks, implies a substantial contribution of unweathered material. Therefore, our lower global average CIX values imply the exported material to be less weathered and hence more reactive than anticipated. Note that the higher values from the literature are not sediment-flux weighted. This observation is significant with respect to the propagated error of the CIX $( \pm 0.1 \mathrm{wt} \%)$ and is potentially explainable by the rivers included in each dataset: coldclimate rivers exhibit lower chemical weathering rates in their catchment (Hartmann et al., 2014b), and mountainous rivers are characterized by steeper terrains and higher erosion rates but less soil formation and chemical weathering (Milliman and Syvitski, 1992; Patton et al., 2018). This explanation is consistent with the marked decrease of our sfw mean CIX compared to the mean and median estimates. The sfw mean is strongly influenced by a few large rivers draining areas of high chemical weathering intensities; i.e. Amazon, Ganga-Brahmaputra, Changjiang, Congo, Irrawaddy, Orinoco, Magdalena, Mekong and Godavari together already deliver $\sim 20 \%$ of the global sediment flux, and South-East Asian drainages contribute as much as $60 \%$ of the global sediment budget (Milliman and Farnsworth, 2011).

\section{Database and code availability}

GloRiSe 1.1 can be downloaded in the form of Excel spreadsheets (.xlsx), comma-separated vectors (.csv) or MATLAB data format (.mat) from Zenodo (http:// doi.org/10.5281/zenodo.4485795, Müller et al., 2021) and GitHub (https://github.com/GerritMuller/GloRiSe.git, last access: 26 May 2021) along with the technical documentation. MATLAB scripts of the presented calculations with all required datasets are available as a supplement to this article. We suggest to download GloRiSe 1.1 from the Zenodo server, because it provides a DOI and a stable version. The GitHub data storage serves for development purposes and 
will regularly be updated. Large updates, involving changes in the database structure, will be noted by an integer number, while smaller updates (addition of samples, corrections) will be noted by the first digit. For reproducibility, we strongly encourage mentioning the GloRiSe version used. The MATLAB code used to produce the example presented in Sect. 5 and through which Fig. 1 can be reproduced is available with detailed explanatory comments on the same page.

\section{Conclusions}

We introduce GloRiSe, a quasi-global database on river sediment composition including major, minor and trace elements along with nutrients and mineralogical data. Observations are placed in a spatio-temporal context by their metadata. This metadata also allow the user to trace back data sources, methods of preparation, measurement details and unit conversion, making the database comprehensible. The dataset is thought to enable global-scale investigation of geochemical fluxes related to erosion, weathering and sediment transport, to serve as a basis for statistical modelling and model validation, to screen promising basins for investigations or complement other datasets. We further provide a MATLAB example script for the calculation of the sediment-flux-weighted mean major element composition of riverine suspended sediment exported each year to the coastal oceans. We complement these estimates with an error analysis that accounts for the variability of sediment fluxes between basins and the uncertainty induced by limited knowledge about the relationship of the size of the sediment flux and its chemical composition. 


\section{Appendix A}

Units of solid concentrations were converted to weight \% of sediment expressed as an oxide, using molar masses and ratios in the following Eq. (A1):

$m(\text { Oxide })_{\mathrm{wt} \%}=\left(\frac{C(\text { Element })_{\mathrm{mol} \%} \times M(\text { Element })}{\left(\frac{M \text { (Element })}{M(\text { Oxide })}\right)}\right)$,

where $C$ denotes concentrations in mol $\%$, while $M$ is the molar mass $(\mathrm{g} / \mathrm{mol})$ and $m$ is the mass percentage relative to the bulk sediment. If concentrations were given relative to the solution volume $(\mathrm{g} / \mathrm{L}$ or $\mathrm{mol} / \mathrm{L})$, they were only included if they were convertible to weight \% of sediment, i.e. when total suspended sediment concentration (TSS) was given (Eq. A2):

$m(\text { Oxide })_{\mathrm{wt}} \% \mathrm{TSS}=\frac{m(\text { Oxide })_{\mathrm{g} / \mathrm{L}}}{\mathrm{TSS}_{\mathrm{g} / \mathrm{L}}} \times 100$.

Solution concentrations are given in $\mu \mathrm{mol} / \mathrm{L}$ and were converted to this using molar masses similar to Eq. (A1). Original units were noted for each entry, and methods of measurement and sample treatment before measurement are specified as stated in the reference to make the data and the conversion comprehensible and reproducible.

\section{Appendix B}

Temporal variability of element concentrations in individual rivers is accompanied by an even larger temporal variability of sediment fluxes (Clark et al., 2017; Cohen et al., 2014; Eberl, 2004; Eiriksdottir et al., 2008; van der Perk and Vilches, 2020; Rousseau et al., 2019) and, thus, imposes a major uncertainty on the basin-wise averages, for which often only very few measurements are available (down to 1 ). We estimated this uncertainty by the mean and maximum deviation of single values from the $\mathrm{sfw}\left(\mathrm{SD}_{\mathrm{sfw}, \mathrm{t}}\right)$ in all available time series ( $>10$ monthly measurements). The mean of all extreme values is $0.3 \mathrm{wt} \%-29.3 \mathrm{wt} \%$, while the mean $\mathrm{SD}_{\text {sfw,t }}$ ranges from $0.1 \mathrm{wt} \%$ to $8.6 \mathrm{wt} \%$ (Table 1). We propagated the mean $\mathrm{SD}_{\mathrm{sfw}, \mathrm{t}}$ (assuming no covariance) through all calculations. This error estimate inherently assumes that event-scale variability is within the month-scale variability, which should be subject to future research. We further ignore measurement errors, suggesting them to be much smaller than seasonal variation. Uncertainties in sediment fluxes in the weighing procedure are also neglected, because intrabasin variability is small compared to differences between basins, the latter spanning several orders of magnitude (Cohen et al., 2014; Milliman and Farnsworth, 2011).
Part of the measured major cations is sorbed to negatively charged mineral surfaces instead of being truly incorporated into the solid phases. To estimate this fraction, we reproduced and utilized a published linear relationship between molar $\mathrm{Al} / \mathrm{Si}$ ratios and cation exchange capacity (CEC), along with estimates of the average major element composition of this sorbed pool (Tipper et al., 2021). With a global average molar $\mathrm{Al} / \mathrm{Si}$ ratio of 0.373 , we arrive at an average CEC of $31.78 \mathrm{meq} / 100 \mathrm{~g}$, implying $0.66 \mathrm{wt} \% \mathrm{Ca}, 0.10 \mathrm{wt} \% \mathrm{Mg}$, $0.02 \mathrm{wt} \% \mathrm{Na}$ and $0.02 \mathrm{wt} \% \mathrm{~K}$ of our sfw mean estimates to be derived from the sorbed pool (Table 1). 
Supplement. The supplement related to this article is available online at: https://doi.org/10.5194/essd-13-3565-2021-supplement.

Author contributions. GM structured the database, selected, collected and harmonized the data, created the evaluation examples, and wrote the manuscript. JJM and AS provided advice on the nature of the data to be collected and feedback on the manuscript.

Competing interests. The authors declare that they have no conflict of interest.

Disclaimer. Despite quality control we cannot guarantee that no errors occurred during the initial data acquisition and publication or during transcription into the database.

Publisher's note: Copernicus Publications remains neutral with regard to jurisdictional claims in published maps and institutional affiliations.

Acknowledgements. This work was carried out under the programme of the Netherlands Earth System Science Centre (NESSC), financially supported by the Ministry of Education, Culture and Science (OCW). Appy Sluijs thanks the European Research Council for Consolidator Grant 771497. We thank Eduardo A. F. Garzanti, Dennis D. Eberl, Grace Andrews, Jérôme Viers and Volker Rachold for clarifying details and searching metadata related to their publications, which were included in the database. These researchers, along with Jens Hartmann, Gibran Romero-Mujalli and Stefan Kempe, are furthermore thanked for discussion and suggestions. We thank Olivier J. T. Sulpis for advice regarding the codes and Gibran Romero-Mujalli for advice regarding database structure and compatibility. Svenja Trapp is thanked for testing user friendliness of the database.

Financial support. This research has been supported by the European Commission, Horizon 2020 Framework Programme (NESSC (grant no. 847504) and an ERC Consolidator Grant (SPANC, no. 771497, awarded to AS)).

Review statement. This paper was edited by Attila Demény and reviewed by Thomas Gloaguen and Thorben Amann.

\section{References}

Allan, J. D. and Castillo, M. M.: Stream Ecology - Structure and Function of Running Waters, Springer, Dordrecht, the Netherlands, 2007.

Bayon, G., Toucanne, S., Skonieczny, C., André, L., Bermell, S., Cheron, S., Dennielou, B., Etoubleau, J., Freslon, N., Gauchery, T., Germain, Y., Jorry, S. J., Ménot, G., Monin, L., Ponzevera, E., Rouget, M. L., Tachikawa, K., and Barrat, J. A.:
Rare earth elements and neodymium isotopes in world river sediments revisited, Geochim. Cosmochim. Ac., 170, 17-38, https://doi.org/10.1016/j.gca.2015.08.001, 2015.

Berner, R. A.: Burial of organic carbon and pyrite sulfur in the modern ocean, Am. J. Sci., 282, 451-473, 1982.

Berner, R. A.: A New Look at the Long-term Carbon Cycle, GSA Today, 9, 2-6, 1999.

Berner, R. A.: Fuels and Atmospheric Composition, Nature, 426, 323-326, available at: http://www.ncbi.nlm.nih.gov/pubmed/ 14628061 (last access: 22 April 2020), 2003.

Beusen, A. H. W., Dekkers, A. L. M., Bouwman, A. F., Ludwig, W., and Harrison, J.: Estimation of global river transport of sediments and associated particulate C, N, and P, Global Biogeochem. Cy., 19, GB4S05, https://doi.org/10.1029/2005GB002453, 2005.

Beusen, A. H. W., Bouwman, A. F., Van Beek, L. P. H., Mogollón, J. M., and Middelburg, J. J.: Global riverine N and P transport to ocean increased during the 20th century despite increased retention along the aquatic continuum, Biogeosciences, 13, 24412451, https://doi.org/10.5194/bg-13-2441-2016, 2016.

Bouchez, J., Gaillardet, J., France-Lanord, C., Maurice, L., and Dutra-Maia, P.: Grain size control of river suspended sediment geochemistry: Clues from Amazon River depth profiles, Geochem. Geophy. Geosy., 12, Q03008, https://doi.org/10.1029/2010GC003380, 2011.

Brantley, S. L., White, A. F., and Kubicki, J. D. (Eds.): Kinetics of water-rock interaction, Springer Science+Business Media, LLC, 233 Spring Street, New York, NY 10013, USA, https://doi.org/10.1007/978-0-387-73563-4, 833 pp., 2008.

Caves Rugenstein, J. K., Ibarra, D. E., and von Blanckenburg, F.: Neogene cooling driven by land surface reactivity rather than increased weathering fluxes, Nature, 571, 99-102, https://doi.org/10.1038/s41586-019-1332-y, 2019.

Cerling, T. E., Pederson, B. L., and Von Damm, K. L.: Sodium-calcium ion exchange in the weathering of shales: implications for global weathering budgets, Geology, 17, 552-554, https://doi.org/10.1130/00917613(1989)017<0552:SCIEIT>2.3.CO;2, 1989.

Clark, K. E., Shanley, J. B., Scholl, M. A., Perdrial, N., Plante, A. F., and Mcdowell, W. H.: Tropical river suspended sediment and solute dynamics in storms during an extreme drought, Water Resour. Res., 53, 3695-3712, https://doi.org/10.1002/2016WR019737, 2017.

Cohen, S., Kettner, A. J., and Syvitski, J. P. M.: Global suspended sediment and water discharge dynamics between 1960 and 2010: Continental trends and intrabasin sensitivity, Global Planet. Change, 115, 44-58, https://doi.org/10.1016/j.gloplacha.2014.01.011, 2014.

Cole, J. J., Prairie, Y. T., Caraco, N. F., McDowell, W. H., Tranvik, L. J., Striegl, R. G., Duarte, C. M., Kortelainen, P., Downing, J. A., Middelburg, J. J., and Melack, J.: Plumbing the global carbon cycle: Integrating inland waters into the terrestrial carbon budget, Ecosystems, 10, 171-184, https://doi.org/10.1007/s10021006-9013-8, 2007.

Conley, D. J.: Terrestrial ecosystems and the global biogeochemical silica cycle, Global Biogeochem. Cy., 16, 68-1-68-8, https://doi.org/10.1029/2002gb001894, 2002.

Eberl, D. D.: Quantitative mineralogy of the Yukon River system: Changes with reach and season, and determin- 
ing sediment provenance, Am. Mineral., 89, 1784-1794, https://doi.org/10.2138/am-2004-11-1225, 2004.

Eiriksdottir, E. S., Louvat, P., Gislason, S. R., Óskarsson, N., and Hardardóttir, J.: Temporal variation of chemical and mechanical weathering in NE Iceland: Evaluation of a steadystate model of erosion, Earth Planet. Sci. Lett., 272, 78-88, https://doi.org/10.1016/j.epsl.2008.04.005, 2008.

Ensign, S. H. and Doyle, M. W.: Nutrient spiraling in streams and river networks, J. Geophys. Res.-Biogeosciences, 111, G04009, https://doi.org/10.1029/2005JG000114, 2006.

Fedo, C. M., Nesbitt, H. W., and Young, G. M.: Unravelling the effects of potassium metasomatism in sedimentary rocks and paleosols, with implications for paleoweathering conditions and provenance, Geology, 23, 921-924, https://doi.org/10.1130/00917613(1995)023<0921:UTEOPM>2.3.CO;2, 1995.

Froelich, P. N., Bender, M. L., Luedtke, N. A., Heath, G. R., and DeVries, T.: The marine phosphorous cycle, Am. J. Sci., 282, 474-511, 1982

Gaillardet, J., Dupré, B., and Allègre, C. J.: Geochemistry of large river suspended sediments: Silicate weathering or recycling tracer?, Geochim. Cosmochim. Ac., 63, 4037-4051, https://doi.org/10.1016/s0016-7037(99)00307-5, 1999.

Galy, V., France-Lanord, C., Beyssac, O., Faure, P., Kudrass, H., and Palhol, F.: Efficient organic carbon burial in the Bengal fan sustained by the Himalayan erosional system, Nature, 450, 407410, https://doi.org/10.1038/nature06273, 2007.

Garzanti, E., Andò, S., France-Lanord, C., Vezzoli, G., Censi, P., Galy, V., and Najman, Y.: Mineralogical and chemical variability of fluvial sediments. 1. Bedload sand (GangaBrahmaputra, Bangladesh), Earth Planet. Sci. Lett., 299, 368381, https://doi.org/10.1016/j.eps1.2010.09.017, 2010.

Garzanti, E., Andó, S., France-Lanord, C., Censi, P., Vignola, P., Galy, V., and Lupker, M.: Mineralogical and chemical variability of fluvial sediments 2. Suspended-load silt (GangaBrahmaputra, Bangladesh), Earth Planet. Sci. Lett., 302, 107120, https://doi.org/10.1016/j.epsl.2010.11.043, 2011.

Garzanti, E., Padoan, M., Setti, M., Najman, Y., Peruta, L., and Villa, I. M.: Weathering geochemistry and Sr-Nd fingerprints of equatorial upper Nile and Congo muds, Geochem. Geophy. Geosy., 14, 292-316, https://doi.org/10.1002/ggge.20060, 2013.

Garzanti, E., Padoan, M., Setti, M., López-Galindo, A., and Villa, I. M.: Provenance versus weathering control on the composition of tropical river mud (southern Africa), Chem. Geol., 366, 61-74, https://doi.org/10.1016/j.chemgeo.2013.12.016, 2014a.

Garzanti, E., Padoan, M., Setti, M., López-Galindo, A., and Villa, I. M.: Provenance versus weathering control on the composition of tropical river mud (southern Africa), Chem. Geol., 366, 61-74, https://doi.org/10.1016/j.chemgeo.2013.12.016, 2014b.

Garzanti, E., Andò, S., Padoan, M., Vezzoli, G., and El Kammar, A.: The modern Nile sediment system: Processes and products, Quaternary Sci. Rev., 130, 9-56, https://doi.org/10.1016/j.quascirev.2015.07.011, 2015.

Gislason, S. R., Oelkers, E. H., and Snorrason, Á.: Role of riversuspended material in the global carbon cycle, Geology, 34, 4952, https://doi.org/10.1130/G22045.1, 2006.

Guo, Y., Yang, S., Su, N., Li, C., Yin, P., and Wang, Z.: Revisiting the effects of hydrodynamic sorting and sedimentary recycling on chemical weathering indices, Geochim. Cosmochim. Ac., 227, 48-63, https://doi.org/10.1016/j.gca.2018.02.015, 2018.

Harnois, L.: The CIW index: A new chemical index of weathering, Sediment. Geol., 55, 319-322, https://doi.org/10.1016/00370738(88)90137-6, 1988.

Hartmann, J., Lauerwald, R., and Moosdorf, N.: A Brief Overview of the GLObal RIver Chemistry Database, GLORICH, Procedia Earth Planet. Sci., 10, 23-27, https://doi.org/10.1016/j.proeps.2014.08.005, 2014a.

Hartmann, J., Moosdorf, N., Lauerwald, R., Hinderer, M., and West, A. J.: Global chemical weathering and associated P-release - the role of lithology, temperature and soil properties, Chem. Geol., 363, 145-163, https://doi.org/10.1016/j.chemgeo.2013.10.025, 2014b.

He, J., Garzanti, E., Dinis, P., Yang, S., and Wang, H.: Provenance versus weathering control on sediment composition in tropical monsoonal climate (South China) - 1. Geochemistry and clay mineralogy, Chem. Geol., 558, 119860, https://doi.org/10.1016/j.chemgeo.2020.119860, 2020.

Hilton, R. G. and West, A. J.: Mountains, erosion and the carbon cycle, Nat. Rev. Earth Environ., 1, 284-299, https://doi.org/10.1038/s43017-020-0058-6, 2020.

Horowitz, A. J. and Elrick, K. A.: The relation of stream sediment surface area, grain size and composition to trace element chemistry, Appl. Geochem., 2, 437-451, https://doi.org/10.1016/08832927(87)90027-8, 1987.

Isson, T. T., Planavsky, N. J., Coogan, L. A., Stewart, E. M., Ague, J. J., Bolton, E. W., Zhang, S., McKenzie, N. R., and Kump, L. R.: Evolution of the Global Carbon Cycle and Climate Regulation on Earth, Global Biogeochem. Cy., 34, e2018GB006061, https://doi.org/10.1029/2018GB006061, 2020.

Jones, M. T., Pearce, C. R., Jeandel, C., Gislason, S. R., Eiriksdottir, E. S., Mavromatis, V., and Oelkers, E. H.: Riverine particulate material dissolution as a significant flux of strontium to the oceans, Earth Planet. Sci. Lett., 355-356, 51-59, https://doi.org/10.1016/j.eps1.2012.08.040, 2012.

Kumar, V., Parihar, R. D., Sharma, A., Bakshi, P., Singh Sidhu, G. P., Bali, A. S., Karaouzas, I., Bhardwaj, R., Thukral, A. K., Gyasi-Agyei, Y., and Rodrigo-Comino, J.: Global evaluation of heavy metal content in surface water bodies: A meta-analysis using heavy metal pollution indices and multivariate statistical analyses, Chemosphere, 236, 124364, https://doi.org/10.1016/j.chemosphere.2019.124364, 2019.

Lasaga, A. C.: Chemical Kinetics of Water-Rock Interactions, J. Geophys. Res., 89, 4009-4025, 1984.

Linke, S., Lehner, B., Ouellet Dallaire, C., Ariwi, J., Grill, G., Anand, M., Beames, P., Burchard-Levine, V., Maxwell, S., Moidu, H., Tan, F., and Thieme, M.: Global hydro-environmental sub-basin and river reach characteristics at high spatial resolution, Sci. data, 6, 283, https://doi.org/10.1038/s41597-019-03006, 2019

Liu, Z., Colin, C., Huang, W., Phon Le, K., Tong, S., Chen, Z., and Trentesaux, A.: Climatic and tectonic controls on weathering in south China and Indochina Peninsula: Clay mineralogical and geochemical investigations from the Pearl, Red, and Mekong drainage basins, Geochem. Geophy. Geosy., 8, Q05005, https://doi.org/10.1029/2006GC001490, 2007.

Liu, Z., Wang, H., Hantoro, W. S., Sathiamurthy, E., Colin, C., Zhao, Y., and Li, J.: Climatic and tectonic controls 
on chemical weathering in tropical Southeast Asia (Malay Peninsula, Borneo, and Sumatra), Chem. Geol., 291, 1-12, https://doi.org/10.1016/j.chemgeo.2011.11.015, 2012.

Ludwig, W., Amiotte-Suchet, P., and Probst, J. L.: River discharges of carbon to the world's oceans: Determining local inputs of alkalinity and of dissolved and particulate organic carbon, Comptes Rendus l'Academie Sci. - Ser. IIa Sci. la Terre des Planetes, 323, 1007-1014, 1996.

Lupker, M., France-Lanord, C., Lavé, J., Bouchez, J., Galy, V., Métivier, F., Gaillardet, J., Lartiges, B., and Mugnier, J. L.: A Rousebased method to integrate the chemical composition of river sediments: Application to the Ganga basin, J. Geophys. Res.-Earth, 116, F04012, https://doi.org/10.1029/2010JF001947, 2011.

Lupker, M., France-Lanord, C., Galy, V., Lavé, J., Gaillardet, J., Gajurel, A. P., Guilmette, C., Rahman, M., Singh, S. K., and Sinha, R.: Predominant floodplain over mountain weathering of Himalayan sediments (Ganga basin), Geochim. Cosmochim. Ac., 84, 410-432, https://doi.org/10.1016/j.gca.2012.02.001, 2012.

Martin, J. and Meybeck, M.: Elemental Mass-Balance of Material Carried By Major World Rivers, Mar. Chem., 7, 173-206, 1979.

Matthews, J. B.: Physics of Climate Change: Harmonic and exponential processes from in situ ocean time series observations show rapid asymmetric warming, J. Adv. Phys., 6, 1135-1171, available at: https://rajpub.com/index.php/jap/article/view/6960 (last access: 20 July 2021), 2014.

McDowell, R. W., Noble, A., Pletnyakov, P., and Mosley, L. M.: Global database of diffuse riverine nitrogen and phosphorus loads and yields, Geosci. Data J., https://doi.org/10.1002/gdj3.111, 2020a.

McDowell, R. W., Noble, A., Pletnyakov, P., Haggard, B. E., and Mosley, L. M.: Global mapping of freshwater nutrient enrichment and periphyton growth potential, Sci. Rep., 10, 3568, https://doi.org/10.1038/s41598-020-60279-w, 2020b.

Meybeck, M.: Carbon, nitrogen, and phosphorus transport by world rivers, Am. J. Sci., 282, 401-450, https://doi.org/10.2475/ajs.282.4.401, 1982.

Meybeck, M. and Ragu, A.: Presenting the GEMS-GLORI, a compendium of world river discharge to the oceans, Freshwater Contamination, in: Proceedings of Rabat Symposium S4, April-May 1997, IAHS Publications, 243, 3-14, https://doi.org/10013/epic.34684.d001, 1997.

Middelburg, J. J., van der Weijden, C. H., and Woittiez, J. R. W.: Chemical processes affecting the mobility of major, minor and trace elements during weathering of granitic rocks, Chem. Geol., 68, 253-273, https://doi.org/10.1016/00092541(88)90025-3, 1988.

Middelburg, J. J., Soetaert, K., and Hagens, M.: Ocean Alkalinity, Buffering and Biogeochemical Processes, Rev. Geophys., 58, e2019RG000681, https://doi.org/10.1029/2019RG000681, 2020.

Milliman, J. D. and Farnsworth, K. L.: River Discharge to the Coastal Ocean: A Global Synthesis, Cambridge University Press, Cambridge, 143-144, https://doi.org/10.1017/cbo9780511781247, 2011.

Milliman, J. D. and Syvitski, J. P. M.: Geomorphic/tectonic control of sediment discharge to the ocean: the importance of small mountainous rivers, J. Geol., 100, 525-544, https://doi.org/10.1086/629606, 1992.
Müller, G., Middelburg, J. J., and Sluijs, A.: Global River Sediments (GloRiSe) v1.1 (Version 1.1), Zenodo [data set], https://doi.org/10.5281/zenodo.4485795, 2021.

Mulligan, M., van Soesbergen, A., and Sáenz, L.: GOODD, a global dataset of more than 38,000 georeferenced dams, Sci. Data, 7, 31, https://doi.org/10.1038/s41597-020-0362-5, 2020.

Nakato, T.: Tests of Selected Sediment-Transport Formulas, J. Hydraul. Eng., 116, 362-379, https://doi.org/10.1061/(asce)07339429(1990)116:3(362), 1990.

Négrel, P. and Grosbois, C.: Changes in chemical and ${ }^{87} \mathrm{Sr} /{ }^{86} \mathrm{Sr}$ signature distribution patterns of suspended matter and bed sediments in the upper Loire river basin (France), Chem. Geol., 156, 231-249, https://doi.org/10.1016/S0009-2541(98)00182-X, 1999.

Nesbitt, H. W. and Young, G. M.: Early proterozoic climates and plate motions inferred from major element chemistry of lutites, Nature, 299, 715-717, https://doi.org/10.1038/299715a0, 1982.

Nienhuis, J. H., Ashton, A. D., Edmonds, D. A., Hoitink, A. J. F., Kettner, A. J., Rowland, J. C., and Törnqvist, T. E.: Globalscale human impact on delta morphology has led to net land area gain, Nature, 577, 514-518, https://doi.org/10.1038/s41586-0191905-9, 2020.

Papanicolaou A. T., Elhakeem, M., Krallis, G., Prakash, S., and Edinger, J.: Sediment Transport Modeling Review Current and Future Developments, J. Hydraul. Eng., 134, 1-14, https://doi.org/10.1061/(ASCE)0733-9429(2008)134:1(1) , 2008.

Parker, A.: An Index of Weathering for Silicate Rocks, Geol. Mag., 107, 501-504, https://doi.org/10.1017/S0016756800058581, 1970.

Patton, N. R., Lohse, K. A., Godsey, S. E., Crosby, B. T., and Seyfried, M. S.: Predicting soil thickness on soil mantled hillslopes, Nat. Commun., 9, 3329, https://doi.org/10.1038/s41467018-05743-y, 2018.

Peucker-Ehrenbrink, B.: Land2Sea database of river drainage basin sizes, annual water discharges, and suspended sediment fluxes, Geochem. Geophy. Geosy., 10, Q06014, https://doi.org/10.1029/2008GC002356, 2009.

Putnis, C. V., Ruiz-Agudo, E., and Hövelmann, J.: Coupled fluctuations in element release during dolomite dissolution, Mineral. Mag., 78, 1355-1362, https://doi.org/10.1180/minmag.2014.078.6.01, 2014.

Romero-Mujalli, G., Hartmann, J., and Börker, J.: Temperature and $\mathrm{CO}_{2}$ dependency of global carbonate weathering fluxes - Implications for future carbonate weathering research, Chem. Geol., 527, 118874, https://doi.org/10.1016/j.chemgeo.2018.08.010, 2019.

Rousseau, T. C. C., Roddaz, M., Moquet, J. S., Handt Delgado, H., Calves, G., and Bayon, G.: Controls on the geochemistry of suspended sediments from large tropical South American rivers (Amazon, Orinoco and Maroni), Chem. Geol., 522, 38-54, https://doi.org/10.1016/j.chemgeo.2019.05.027, 2019.

Rudnick, R. L. and Gao, S.: Composition of the Continental Crust, in: Treatise on Geochemistry (Second edn.), 4, 1-51, https://doi.org/10.1016/B978-0-08-095975-7.00301-6, 2014.

Ruiz-Agudo, E., King, H. E., Patiño-Ĺpez, L. D., Putnis, C. V., Geisler, T., Rodriguez-Navarro, C., and Putnis, A.: Control of silicate weathering by interface-coupled dissolutionprecipitation 
processes at the mineral-solution interface, Geology, 44, 567570, https://doi.org/10.1130/G37856.1, 2016.

Savenko, V. S.: Chemical composition of sediment load carried by rivers, Geochem. Int., 45, 816-824, https://doi.org/10.1134/S0016702907080071, 2007.

Stroncik, N. A. and Schmincke, H.-U.: Evolution of palagonite: Crystallization, chemical changes, and element budget, Geochem. Geophy. Geosy., 2, 2000GC000102, https://doi.org/10.1029/2000GC000102, 2001.

Tipper, E. T., Stevenson, E. I., Alcock, V., Knight, A. C. G., Baronas, J. J., Hilton, R. G., Bickle, M. J., Larkin, C. S., Feng, L., Relph, K. E., and Hughes, G.: Global silicate weathering flux overestimated because of sediment-water cation exchange, P. Natl. Acad. Sci. USA, 118, e2016430118, https://doi.org/10.1073/pnas.2016430118, 2021.

van der Perk, M. and Vilches, A. E.: Compositional dynamics of suspended sediment in the Rhine River: sources and controls, J. Soils Sediments, 20, 1754-1770, https://doi.org/10.1007/s11368-019-02490-5, 2020.

Viers, J., Dupré, B., and Gaillardet, J.: Chemical composition of suspended sediments in World Rivers: New insights from a new database, Sci. Total Environ., 407, 853-868, https://doi.org/10.1016/j.scitotenv.2008.09.053, 2009.
Virro, H., Amatulli, G., Kmoch, A., Shen, L., and Uuemaa, E.: GRQA: Global River Water Quality Archive, Earth Syst. Sci. Data Discuss. [preprint], https://doi.org/10.5194/essd-2021-51, in review, 2021.

von Eynatten, H.: Statistical modelling of compositional trends in sediments, Sediment. Geol., 171, 79-89, https://doi.org/10.1016/j.sedgeo.2004.05.011, 2004.

von Eynatten, H., Tolosana-Delgado, R., and Karius, V.: Sediment generation in modern glacial settings: Grain-size and source-rock control on sediment composition, Sediment. Geol., 280, 80-92, https://doi.org/10.1016/j.sedgeo.2012.03.008, 2012.

Vörösmarty, C. J., McIntyre, P. B., Gessner, M. O., Dudgeon, D., Prusevich, A., Green, P., Glidden, S., Bunn, S. E., Sullivan, C. A., Liermann, C. R., and Davies, P. M.: Global threats to human water security and river biodiversity, Nature, 467, 555-561, https://doi.org/10.1038/nature09440, 2010.

Weigelhofer, G., Hein, T., and Bondar-Kunze, E.: Phosphorus and Nitrogen Dynamics in Riverine Systems: Human Impacts and Management Options, in: Riverine Ecosystem Management, edited by: Schmutz, S. and Sendzimir, J., vol. 8, Springer, Cham, https://doi.org/10.1007/978-3-319-73250-3_10, 2018. 